\title{
PHALARIS SEED PRODUCTION: CONTROL OF RUMEX AND HERBICIDE TOLERANCE
}

\author{
K. REDDY, M.P. ROLSTON and W.J. ARCHIE
}

\author{
AgResearch, P.O. Box 60, Lincoln
}

\begin{abstract}
Control of Rumex species in phalaris (Phalaris aquatica L.) by four herbicides and tolerance of phalaris seed crops to a range of herbicides was investigated in two trials. Dicamba at $400 \mathrm{~g} /$ ha gave $100 \%$ control of Rumex species in both years ( 0 and 1 Rumex seed $/ 40 \mathrm{~g}$ phalaris seed). Thifensulfuron at $15 \mathrm{~g} /$ ha gave $100 \%$ and 99.7 control (0 and 15 seeds/ $40 \mathrm{~g})$. These treatments were more effective than asulam or a 2,4-D + dicamba mixture. Phalaris seed yields had good tolerance to mecoprop and dichlorprop mixtures, tribenuron-methyl, TCA + 2,2-DPA, prodiamine, and diflufenican + bromoxynil. Fenoxyprop-P-ethyl is not recommended for phalaris seed crops.
\end{abstract}

Keywords: herbicide, Phalaris aquatica, Rumex, seed production.

\section{INTRODUCTION}

Phalaris (Phalaris aquatica L.) is persistent on drought prone areas, has good winter productivity (Stevens et al. 1989) and excellent tolerance to grass grub (French et al. 1983). Producing quality seed of phalaris is a problem because of contamination by Rumex species (dock), mainly Rumex obtusifolius. Rumex is a declared species for importation into most markets, including Australia (a major user of Phalaris seed) where the number of seeds/40 g must be declared on the purity and germination certificate. Zero contamination by Rumex is preferred by buyers, but most will accept lines with one to three Rumex seeds $/ 40 \mathrm{~g}$. The seeds of Rumex species are extremely difficult to separate during the seed cleaning process because their size and structure are similar to that of phalaris seeds especially when the paper-like wing structures on the seeds are broken off during the threshing process. Therefore, Rumex species need to be removed from phalaris seed crops before harvest. However, growers have been reluctant to use herbicides such as dicamba, as some believe this causes seed yield reductions (J. Morrow, pers. comm.).

There have been few studies on the tolerance of seedling phalaris to different herbicides (Rolston and Hare 1986a). Common problems with phalaris are that it tends to germinate slowly and irregularly (McWilliamet al. 1970) and has a poor competitive ability especially in the seedling year (Stevens et al. 1989). Interference by annual weeds is therefore a major problem in establishing phalaris for seed production. Seed yield reductions of between 6 and $19 \mathrm{~kg}$ for every $1 \%$ increase in weed cover were reported in two trials (Rolston and Hare 1986b).

This paper reports on Rumex species control and the tolerance of the first year phalaris seed crop to different herbicides suitable for the control of broad leaf and grass weeds.

\section{MATERIALS AND METHODS}

The trials were sown with phalaris (Phalaris aquatica) cv. Grasslands Maru at a seed rate of $7 \mathrm{~kg} / \mathrm{ha}$ at $15 \mathrm{~cm}$ row spacings. Herbicides were applied with a gas propelled sprayer at $220 \mathrm{kPa}$ in 250 litres water/ha. The crops received $150 \mathrm{~kg} \mathrm{~N} / \mathrm{ha}$ as urea in early and late spring. Seed was harvested at $40 \%$ seed moisture (Reddy et al. 1993) and dried in hessian bags, before being threshed, cleaned and weighed to determine seed yield. The number of Rumex species seeds was assessed on $40 \mathrm{~g}$ samples, this being the normal method for reporting Rumex species contamination in phalaris on international seed trade certificates.

Proc. 51st N.Z. Plant Protection Conf. 1998: 80-83 


\section{Trial 1}

Four herbicides for Rumex species control were evaluated on a farm at Lowcliff, Ashburton. The crop was established in late January 1994 on a Wakanui silt loam (pH 5.7, Olsen P 30 ppm). Herbicides were applied on 30 September 1994 using a factorial randomised complete block design with four replications with a plot size of $24 \mathrm{~m}^{2}$. The herbicide treatments and application rates used were; asulam (Asulox) $1600 \mathrm{~g} / \mathrm{ha}$; dicamba $400 \mathrm{~g} / \mathrm{ha}$; thifensulfuron (Harmony) $15 \mathrm{~g} / \mathrm{ha}$ and 2,4-D + dicamba (Banvine) $800+400 \mathrm{~g} / \mathrm{ha}$. The average Rumex density was 3.4 plants $/ \mathrm{m}^{2}$.

\section{Trial 2}

Using the same crop in the second year (1995), the two most effective herbicide treatments, thifensulfuron (15 g / ha) and dicamba (400 g / ha), were re-evaluated. Herbicides were applied on 20 October 1995 using a factorial randomised complete block design with 4 replications and a plot size of $60 \mathrm{~m}^{2}$. The average Rumex density was 1.1 plants $/ \mathrm{m}^{2}$.

\section{Trial 3}

The third trial evaluated the tolerance of phalaris to a range of herbicides and was established in March 1995 at the AgResearch Farm, Boundary Road, Lincoln. The trial was sown with an 'Oyjord' cone seeder, in four blocks $1.35 \mathrm{~m}$ wide and $43 \mathrm{~m}$ long. Each block was interspersed with other grass species. Within each block, one or more herbicides were evaluated at two rates and each block contained three replicates with untreated controls. Individual plots were $2.5 \mathrm{~m}$ x $1.35 \mathrm{~m}$. The herbicides evaluated were: fenoxyprop-P-ethyl (Puma S), a wild oat herbicide applied in mid September; TCA + 2,2-DPA (Teedal) applied in late June; prodiamine (Barricade) applied in mid June; diflufenican + bromoxynil (Jaguar), applied in late June; mecoprop + bromoxynil + ioxynil (Axall) applied in late June; dichloprop + mecoprop + MCPA + dicamba (Salvo) applied in mid June; tribenuron-methyl (Granstar) applied in late August; thifensulfuron (Harmony) applied in late August and quizalofop-P-ethyl (Targa) applied in mid June. The herbicide rates are presented in Table 2.

\section{RESULTS AND DISCUSSION}

TABLE 1: Effects of herbicides on phalaris seed yield and quality.

\begin{tabular}{|c|c|c|c|c|c|c|c|}
\hline \multirow[b]{2}{*}{ Herbicide } & \multirow[b]{2}{*}{$\begin{array}{l}\text { Rate } \\
\text { (g ai /ha) }\end{array}$} & \multicolumn{3}{|c|}{ Phalaris } & \multicolumn{3}{|c|}{ Rumex species } \\
\hline & & $\begin{array}{c}\text { Seed } \\
\text { yield } \\
(\mathrm{kg} / \mathrm{ha})\end{array}$ & $\begin{array}{c}\text { Germ- } \\
\text { ination } \\
(\%)\end{array}$ & $\begin{array}{c}\text { Thousand } \\
\text { seed wt } \\
\text { (g) }\end{array}$ & $\begin{array}{c}\text { Seed } / 40 \mathrm{~g} \\
\text { sample } \\
\text { (No.) }\end{array}$ & & $\begin{array}{l}\text { Thousand } \\
\text { seed wt } \\
\text { (g) }\end{array}$ \\
\hline untreated control & & 480 & 73 & 1.45 & 1977 & & 1.14 \\
\hline asulam & 1600 & 483 & 61 & 1.35 & 38 & $25 *$ & 0.84 \\
\hline 2,4-D + dicamba & $800+400$ & 456 & 74 & 1.54 & 45 & $36 *$ & 0.97 \\
\hline dicamba & 400 & 500 & 78 & 1.50 & 1 & $2 *$ & 0.36 \\
\hline thifensulfuron & 15 & 536 & 74 & 1.48 & 15 & $14 *$ & 0.48 \\
\hline LSD $(\mathrm{P}<0.05)$ & & 83.8 & 10 & 0.21 & 104 & 25 & 0.81 \\
\hline
\end{tabular}

* Adjusted mean without control and with covariant as initial Rumex spp. plant population

\section{Rumex species control}

The four herbicide treatments, asulam, 2,4-D + dicamba, dicamba and thifensulfuron provided significant control of Rumex species (Table 1) reducing seed contamination by at least $97 \%$. The untreated control plots had 7\% Rumex contamination. Only dicamba reduced Rumex seed numbers to an acceptable trading level $(\geq 3$ seeds $/ 40 \mathrm{~g}$ phalaris). The dicamba treatment also gave a significant reduction in Rumex seed number when the four herbicides were compared without the control plots. On a weight $\%$ basis, the dicamba and thifensulfuron plots contained 0.003 and $0.053 \%$ Rumex respectively. There was no detrimental effect of any of the herbicides on 
phalaris seed yield and seed weight but the asulam treatment reduced seed germination (Table 1). Seed germination in phalaris is sensitive to the stage of seed maturity (Reddy et al. 1993). The germination reduction in the asulam treatment may result from delayed seed maturity rather than any permanent effect.

Two weeks after application of dicamba and 2,4-D + dicamba, the phalaris crop showed phytotoxic symptoms with all the expanded leaves of phalaris being flaccid and lying on the soil surface; however plants recovered in 3-4 weeks. Asulam caused the crop to yellow, but this was only a temporary response.

In the second trial (year 2), thifensulfuron and dicamba gave $100 \%$ control of Rumex species with no Rumex seeds in the sample. The control had $23 \%$ Rumex seeds, three times more than in Trial 1. In pasture trials, thifensulfuron at 15-20 g/ha resulted in good control of three Rumex species (James et al. 1992). The phalaris seed yield from the two herbicide treatments were equal to or better than the control which had a yield of $430 \mathrm{~kg} / \mathrm{ha}$. There were no phytotoxic symptoms from the herbicide in the second year. The better control of Rumex in the second year, with thifensulfuron, may reflect the later application date as this herbicide is more effective under warmer conditions and when Rumex are actively growing (G. Iggo, pers. comm).

\section{Crop tolerance to herbicide}

Hormone based herbicides have traditionally been used for broadleaf weed control in grass seed crops and often applied in late winter or early spring. Hormone based herbicides registered for use in ryegrass and some other grass seed crops include mixes that contain dicamba, dichlorprop, MCPA or mecoprop. Non-hormone herbicides for ryegrass seed crops include bromoxynil, ioxynil and diflufenican.

In this trial, the control of autumn weeds and consequent removal of competition resulted in a significant yield response (Table 2). The results are expressed as relative seed yields to allow easy comparison between herbicide blocks. The mean seed yield of the control plots was $205 \mathrm{~kg} / \mathrm{ha}$. Phalaris had good tolerance to mecoprop + bromoxynil + ioxynil and dichlorprop + mecoprop + MCPA + dicamba applied at double the recommended label rates for grass seed crops or cereals.

\section{TABLE 2: Relative seed yield (control=100) of phalaris treated with different herbicides.}

\begin{tabular}{llr}
\hline Herbicides & Rates (g ai/ha) & Relative seed yield ${ }^{1}$ \\
\hline untreated control & & $100 \mathrm{~b}$ \\
diflufenican + bromoxynil & $25+250$ & $88 \mathrm{~b}$ \\
diflufenican + bromoxynil & $37.5+375$ & $95 \mathrm{~b}$ \\
diflufenican + bromoxynil & $75+750$ & $99 \mathrm{~b}$ \\
mecoprop + bromoxynil + ioxynil & $1035+22.5+22.5$ & $99 \mathrm{~b}$ \\
mecoprop + bromoxynil + ioxynil & $2070+45+450$ & $145 \mathrm{a}$ \\
dichlorprop + mecoprop + & & \\
$\quad$ MCPA + dicamba & $699+630+321+51$ & $140 \mathrm{a}$ \\
tribenuron & 11.25 & $116 \mathrm{~b}$ \\
tribenuron & 22.5 & $138 \mathrm{a}$ \\
thifensulfuron & 15 & $109 \mathrm{~b}$ \\
thifensulfuron & 30 & $130 \mathrm{~b}$ \\
quizalofop & 50 & $0 \mathrm{~d}$ \\
fenoxaprop & 37.5 & $20 \mathrm{~d}$ \\
fenoxaprop & 75 & $5 \mathrm{~d}$ \\
TCA + 2,2-DPA & $3150+550$ & $113 \mathrm{~b}$ \\
TCA + 2,2-DPA & $4725+825$ & $58 \mathrm{c}$ \\
prodiamine & 650 & $171 \mathrm{a}$ \\
prodiamine & 1300 & $105 \mathrm{~b}$ \\
\hline
\end{tabular}

${ }^{1}$ Means followed by the same letter are not significantly different (separated by LSD $0.05)$ 
Late removal of broadleaf weeds by tribenuron at a higher rate resulted in a large yield increase. Tribenuron has recently been registered for grass seed crops in Norway and the USA (Rolston et al. 1997). In New Zealand, tribenuron is registered for use in cereals, while trifensulfuron is registered for dock and buttercup control in pastures. Both herbicides are low cost. Further work is needed to define how early these products can be used on grass seed crops, for instance application in autumn or winter rather than in spring.

The grass weed control herbicides gave variable results. Fenoxyprop controls wild oats and the annual phalaris species Phalaris minor. This herbicide was also very active on perennial phalaris (Table 2) and is not suitable for use in Maru phalaris seed crops. Maru phalaris showed good tolerance to TCA + 2,2-DPA $(3150+550 \mathrm{~g} / \mathrm{ha})$ but a significant reduction in seed yield occurred when this rate was increased by $50 \%$ (Table 2). This level of tolerance means that control of annual grasses including soft brome (Bromus hordeacus), barley grass (Hordeum leporinum) and Poa annua would be marginal, although volunteer cereals may be controlled.

Phalaris showed good tolerance to prodiamine at the rate of $650 \mathrm{~g} / \mathrm{ha}$ but significant reduction in seed yield was observed at a higher rate of $1300 \mathrm{~g} / \mathrm{ha}$ (Table 2). Prodiamine is used in the USA pre-emergence for Poa annua control in established turf. The usefulness of this herbicide in phalaris is limited.

The grass control herbicide quizalofop applied at the low rate of $50 \mathrm{~g} / \mathrm{ha}$ was not tolerated by phalaris and is therefore not recommended for use on phalaris seed crops.

\section{CONCLUSION}

The trials have demonstrated that Rumex can be controlled in phalaris seed crops to meet export standards. The timing of dicamba application may be less critical than with thifensulfuron. Higher rates of broad leaf weed control herbicides often gave higher seed yields suggesting that phalaris is sensitive to weed competition. A spring applied broadleaf control herbicide (e.g. tribenuron) could be applied to control any weeds escaping from an autumn/early winter control programme.

\section{ACKNOWLEDGEMENTS}

The authors wish to thank Agricom NZ Ltd, Technologies for Business Growth, and the Foundation for Arable Research for financial support; John Morrow for access to his farm for Trials 1 and 2; and Santosh Roy for technical assistance.

\section{REFERENCES}

French, R.A., Pearson, J.F., Vartha, E.W. and Fraser, T.J., 1983. Grass grub: coping without chemical control. Proc. N. Z. Grassland Assoc. 44: 217-221.

James, T.K., Rahman, A. and Cornwell, M.J., 1992. Control of docks and buttercups with thifensulfuron in pasture. Proc. 45th N.Z. Plant Prot. Conf:: 226-230.

McWilliam, J.R., Clements, R.J. and Dowling, P.M., 1970. Some factors influencing the germination and early seedling development of pasture plants. Australian J. Agri. Res. 21:19-32.

Reddy, K., Scott, W. R. and Lucas, R.J., 1993. Influence of harvest date on the yield and quality of seed of phalaris. XV11 International Grassland Congress:16851686.

Rolston, M.P. and Hare M.D., 1986a. Herbicides for grass seed crops. 1. Seedling browntop, phalaris and tall fescue seed crops. Proc. 39th N. Z. Weed and Pest Control Conf: : 45-48.

Rolston, M.P. and Hare M.D., 1986b. Competitive effects of weeds on seed yield of first year grass seed crops. J. Appl. Seed Prod. 4: 34-36.

Rolston, M.P., Mueller-Warrant, G. and Aamlid, T., 1997. Use of tribenuron on grass seed crops. International Herbage Seed Production Research Group Newsletter 26: 2.

Stevens, J.R., Turner, J.D., Baker, D.J. and Moloney, S., 1989. Grasslands Maru phalaris: production and persistence in hill country. Proc. N.Z. Grassland Assoc. 50: 230-231. 